\title{
The beneficial fungus Piriformospora indica protects Arabidopsis from Verticillium dahliae infection by downregulation plant defense responses
}

Chao Sun ${ }^{1}$, Yongqi Shao ${ }^{2}$, Khabat Vahabi ${ }^{1}$, Jing Lu ${ }^{2,6}$, Samik Bhattacharya ${ }^{2}$, Sheqin Dong ${ }^{3}$, Kai-Wun Yeh $^{4}$, Irena Sherameti ${ }^{1}$, Binggan Lou ${ }^{5}$, lan T Baldwin' ${ }^{2}$ and Ralf Oelmüller ${ }^{1^{*}}$

\begin{abstract}
Background: Verticillium dahliae $(V d)$ is a soil-borne vascular pathogen which causes severe wilt symptoms in a wide range of plants. The microsclerotia produced by the pathogen survive in soil for more than 15 years.

Results: Here we demonstrate that an exudate preparation induces cytoplasmic calcium elevation in Arabidopsis roots, and the disease development requires the ethylene-activated transcription factor EIN3. Furthermore, the beneficial endophytic fungus Piriformospora indica $(P i)$ significantly reduced $V d$-mediated disease development in Arabidopsis. $P i$ inhibited the growth of $V d$ in a dual culture on PDA agar plates and pretreatment of Arabidopsis roots with Pi protected plants from Vd infection. The Pi-pretreated plants grew better after $V d$ infection and the production of $V d$ microsclerotia was dramatically reduced, all without activating stress hormones and defense genes in the host.

Conclusions: We conclude that $P i$ is an efficient biocontrol agent that protects Arabidopsis from Vd infection. Our data demonstrate that $\mathrm{Vd}$ growth is restricted in the presence of $\mathrm{Pi}$ and the additional signals from Pi must participate in the regulation of the immune response against $V d$.
\end{abstract}

Keywords: Calcium, Defense, Ethylene, Jasmonic acid, Piriformospora indica, Salicylic acid, Verticillium dahliae

\section{Background}

Verticillium species are wide-spread soil-borne fungi which cause vascular diseases in many plant species and are responsible for devastating diseases for plants that can thwart agricultural production. The vascular wilt fungus Verticillium dahliae $(V d)$, for instance, infects more than 200 plant species, among them agriculturally and horticulturally important crops and ornamental plants [1-3]. It is estimated that $V d$ infections are responsible for several billions of dollars of annual crop losses worldwide. $V d$ has a broad host range and infects plants from temperate to subtropical climates [1]. Because of their complex life style of the Verticillium species, their control by classical pesticides

\footnotetext{
*Correspondence: b7oera@uni-jena.de

${ }^{1}$ Institute of Plant Physiology, Friedrich-Schiller-University Jena, Dornburger Str. 159, 07743 Jena, Germany

Full list of author information is available at the end of the article
}

or fungicides is difficult; therefore, the isolation of Verticillium-resistant cultivars is an important task for the breeders (cf. $[4,5]$ ).

Genetic resistance against Verticillium wilt diseases has been reported for several plant species [1,2]. The Ve gene provides resistance against race 1 isolates of $V d$ in tomato $[6,7]$ and the tomato gene is also functional after expression in Arabidopsis [8]. Many studies have used Arabidopsis for the isolation of $\mathrm{Vd}$-resistant germplasm $[9,10]$ or the identification of novel resistance traits following mutagenesis [2,10-14]. Furthermore, quite recently, a large number of proteins and metabolites from different organisms as well as phytohormones have been described to be involved in establishing partial resistance against Verticillium wilt [15-22].

Like other Verticillium species, $V d$ can overwinter as mycelium in host plants or soil. The fungus can also form 
seed-like structures called microsclerotia, long-lived survival structures of clusters of melanized cells with thick walls, which survive in the soil without a host plant or in association with plant material for up to 20 years $[23,24]$. The microsclerotia germinate in response to stimuli from root exudates [25]. The hyphae penetrate and grow inter- and intracellularly through the root cortex toward the central cylinder of the root $[26,27]$. They enter the xylem cells of the root, from where they colonize the xylem of the hypocotyl and leaves. Ultimately, the water transport is disrupted which results in the wilt phenotype [1-3]. Verticillium species are considered as hemibiotroph: a biotrophic phase within root xylem without a visible disease phenotype is followed by a necrotrophic phase in the aerial parts of the plant.

The spread of the pathogen occurs primarily by root infections from the soil. Therefore rhizosphere bacterial strains such as Pseudomonas putida B E2, Pseudomonas chlororaphis K15 or Serratia plymuthica R12 [28] or bacterial isolates [29] have been shown to function as efficient biocontrol agents against $V d$ spread. The microbial bioagents induce antibiosis, parasitism, competition and secretion of enzymes such as glucose oxidase, chitinase and glucanase which results in the induction of disease resistance in the hosts [12,30].

To our knowledge, there is no report on endophytic fungi which can be used as biocontrol agent against $V d$ in Arabidopsis. Piriformospora indica (Pi), a cultivable basidiomycete of Sebacinales, colonizes the roots of many plant species including Arabidopsis [31,32]. Like other members of Sebacinales, $P i$ is found worldwide in association with roots [33] and stimulates growth, biomass and seed production of the hosts [31,34-36]. The fungus promotes nitrate and phosphate uptake and metabolism [35,37]. Pi also confers resistance against abiotic $[38,39]$ and biotic stress $[40]$.
Here, we demonstrate that $P i$ is an efficient biocontrol agent that protects Arabidopsis from $V d$ infection in vitro and in vivo by inhibiting growth of $V d$ in roots. Furthermore, we give evidence that a $V d$-exudate compound induces cytoplasmic $\mathrm{Ca}^{2+}\left(\left[\mathrm{Ca}^{2+}\right]_{\text {cyt }}\right)$ elevation and the $\mathrm{Vd}$-disease development is dependent on the ethylene-activated transcription factor EIN3.

\section{Results}

\section{$P i$ inhibits growth of $V d$ on PDA agar plates}

$\mathrm{Pi}$ and $\mathrm{Vd}$ were co-cultivated as described in Methods on a PDA agar plate for 3 weeks. Figure 1(A and B) demonstrates that $P i$ strongly inhibits growth of $V d$ hyphae. The $V d$ colony in the dual culture is significantly smaller than the $V d$ colony growing without $P i$. Furthermore, the number of microsclerotia produced by $V d$ in the dual culture is less than the number of microsclerotia produced by $V d$ growing alone. No obvious inhibition zone can be detected. In contrast, growth of $P i$ is barely affected by the presence of $V d$. This prompted us to test the role of $P i$ in protecting Arabidopsis plants against $V d$ infection.

\section{Arabidopsis seedlings pretreated with $\mathrm{Pi}$ are protected against $V d$ infection}

To investigate whether $P i$ can protect Arabidopsis for $V d$ infection, we exposed the seedlings first to $P i$ prior to $V d$ infection. Seedlings not exposed to any of the two fungi or to one of the two fungi alone served as controls (cf. Methods). The performance of the seedlings was measured after 10, 14 and 21 days, by visible inspection and measuring the fresh weights. After 10 days of cocultivation, seedlings treated with $\mathrm{Vd}$ or $\mathrm{Pi}$ alone showed $\sim 30 \%$ increase in the biomass compared to the untreated control seedlings. A comparable increase in the biomass was observed when the seedlings were first exposed to $P i$ and then to $V d$ or vice versa (Figure $2 \mathrm{~A}$ ). This slight

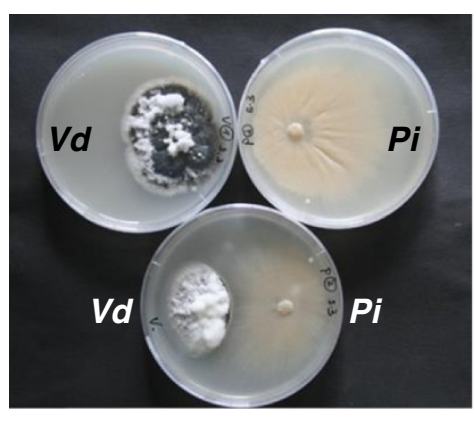

A

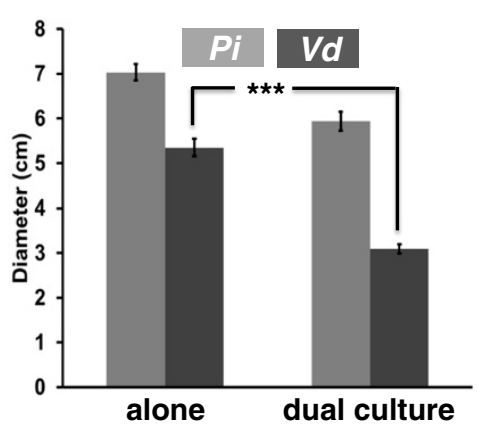

B

Figure 1 Pi inhibits growth of $\boldsymbol{V} \boldsymbol{d}$ on agar plates. (A) Typical plates from 3 independent experiments are shown. (B) Quantification of the colony. The diameter of the Pi and Vd mycelia on the agar plate is given in $\mathrm{cm}$. Bars represent SDs. Asterisks indicate significant differences, as determined by ANOVA (*** $P \leq 0.001)$ 


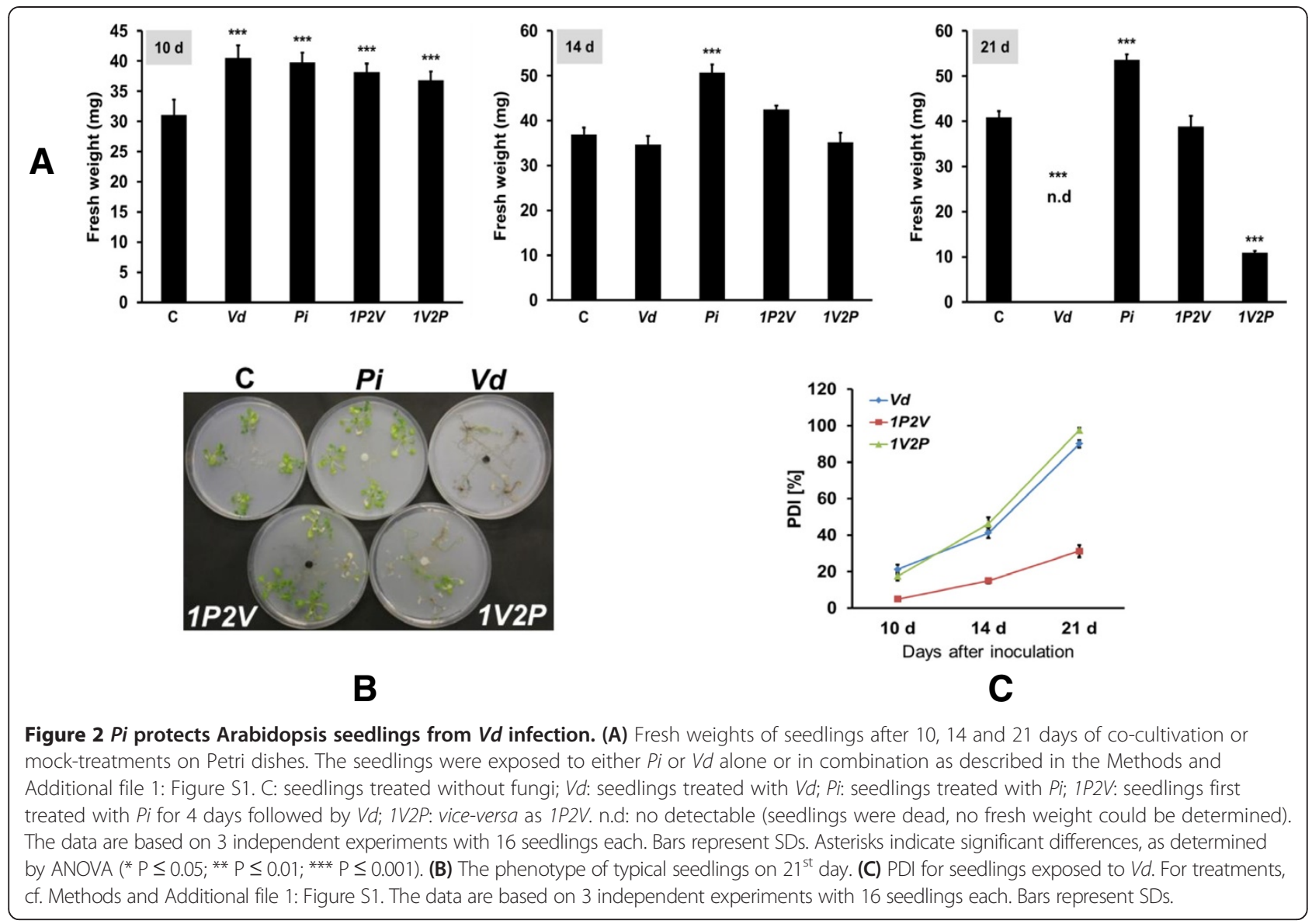

increase in the biomass suggests that both fungi initially form a beneficial interaction with the seedlings, and is consistent with the idea that this phase represents a biotrophic interaction of $V d$ with Arabidopsis roots. On the $14^{\text {th }}$ day, seedlings infected by $V d$ alone or first with $V d$ followed by $\mathrm{Pi}(1 \mathrm{~V} 2 \mathrm{P})$ showed obviously the disease symptoms. The leaves of these seedlings became paler and the roots browner compared to the seedlings exposed to $\mathrm{Pi}$ or $1 \mathrm{P} 2 \mathrm{~V}$ treatments, although no significant differences in the biomass were observed for the different fungal treatments, except for $P i$ treatment (Figure 2A). In contrast, on the $21^{\text {st }}$ day, seedlings exposed to $V d$ alone or exposed to $V d$ prior to exposure to $P i(1 \mathrm{~V} 2 \mathrm{P})$ were severely damaged. Their fresh weights were reduced or no longer measurable. $P i$ treatment alone resulted in a $\sim 30 \%$ increase in the fresh weight (Figure 2A). Interestingly, seedlings which were pretreated with $P i$ and then exposed to $V d(1 P 2 V)$ had the same fresh weights as untreated control seedlings, although the visible inspection showed some photobleaching (Figure 2B). This clearly demonstrates that $P i$ protects Arabidopsis seedlings against $V d$-induced wilt. Therefore, this experimental set-up was used to study the protective function of $P i$ in greater details.
The results were confirmed by calculating the Percentage Disease Index (PDI) for those seedlings treated with $V d$. After 10 days of co-cultivation, the PDI for $V d$ and $1 V 2 P$ seedlings was $\sim 20 \%$, and after 14 days $40-50 \%$. After 21 days, the PDI was almost $100 \%$. In contrast, seedlings pretreated with $P i$ prior to exposure to $V d(1 P 2 V)$ showed a slow increase in the PDI, which reached $\sim 30 \%$ after 21 days (Figure $2 \mathrm{C}$ ).

Furthermore, the amount of total chlorophyll (Chl) is a sensitive marker for the fitness of a plant. On the $4^{\text {th }}$ day, the shoots of $\mathrm{Vd}$ - and $\mathrm{Pi}$ - treated plants contained slightly higher $\mathrm{Chl}$ levels than control seedlings (Figure 3). On the $10^{\text {th }}$ day, the Chl content of $\mathrm{Vd}$ treated seedlings is comparable to that of control seedlings not exposed to the pathogen. Furthermore, while $1 P 2 \mathrm{~V}$ seedlings had the same amount of $\mathrm{Chl}$ as $\mathrm{Pi}$ seedlings, the Chl content in $1 \mathrm{~V} 2 \mathrm{P}$ seedlings was significantly reduced (Figure 3). Comparable results were obtained for the $14^{\text {th }}$ day, except that the Chl content for $1 P 2 \mathrm{~V}$ seedlings was reduced compared to $P i$ seedlings (Figure 3). On the $21^{\text {st }}$ day, $P i$ seedlings had the highest Chl content, $1 P 2 \mathrm{~V}$ seedlings had the same amount of $\mathrm{Chl}$ as control seedlings not exposed to a fungus, while 

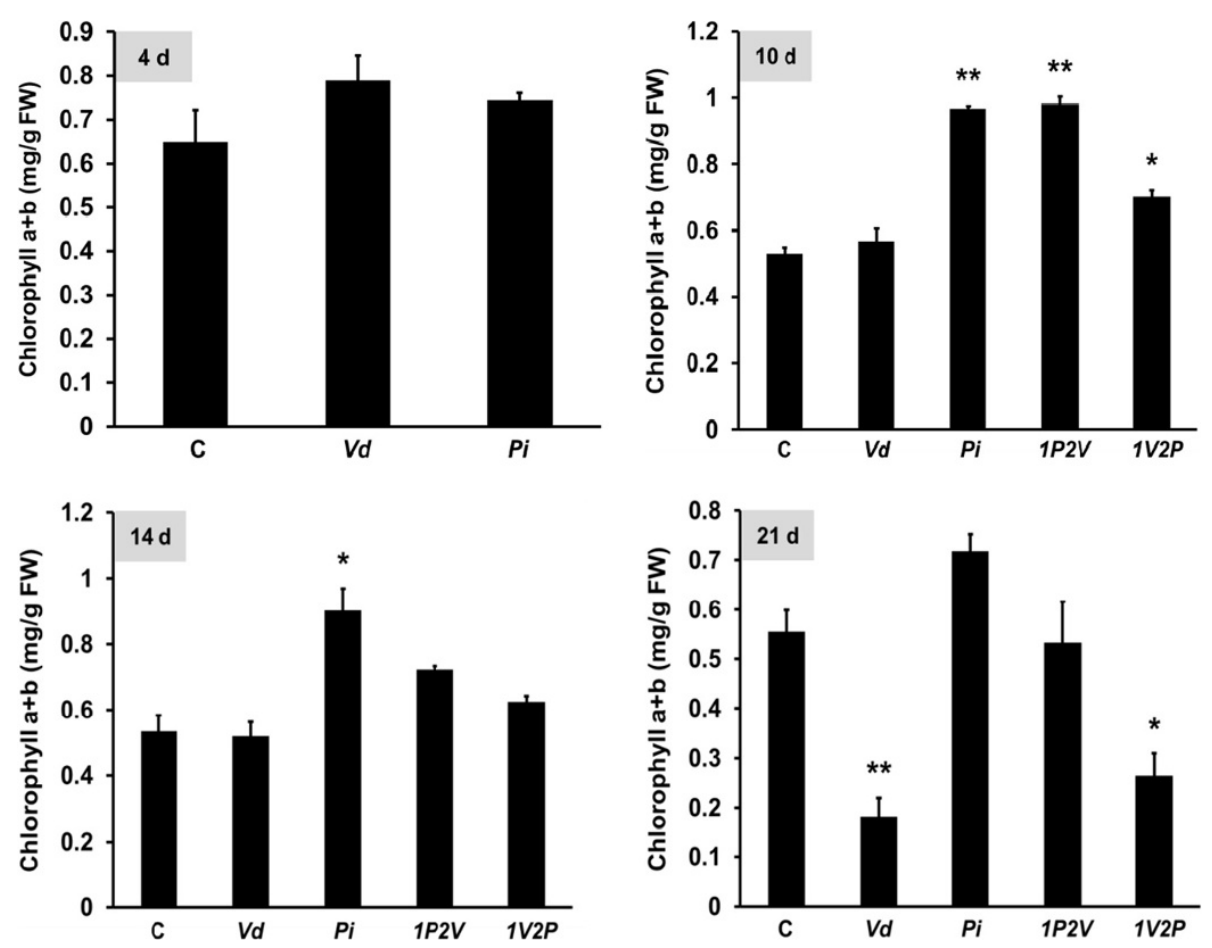

Figure 3 Total chlorophyll content (mg/g fresh weight) in shoots. The data were obtained 4, 10, 14 and 21 days after the fungal treatments (cf. Methods, Additional file 1: Figure S1 and legend to Figure 2A). The data are based on 3 independent experiments with 16 seedlings each. Bars represent SDs. Asterisks indicate significant differences to the untreated control, as determined by Student's t-test $\left({ }^{*} P \leq 0.05 ;{ }^{* *} P \leq 0.01\right.$; *** $P \leq 0.001)$.

the Chl levels in the $V d$ and $1 V 2 P$ plants were strongly decreased (Figure 3). This confirms the protective function of $P i$ against $V d$ infection in Arabidopsis leaves.

Pathogenesis and application of pathogen-associated molecular patterns induce stomata closure [41]. In control plants not exposed to any fungus, between 5 and $12 \%$ of the stomata were closed. Three days after exposure of the roots to $V d, \sim 25 \%$ of the stomata were closed (Figure $4 \mathrm{~A}$ ), and this increased to $\sim 30 \%$ until the $7^{\text {th }}$ day. The $1 V 2 P$ treatment showed $\sim 25 \%$ stomata closure at the $7^{\text {th }}$ day, and this value is comparable to that for seedlings treated with $V d$ alone. In contrast, exposure of the roots to $P i$ or first to $P i$ followed by $V d$ did not result in stomata closure and these values are comparable to those of the untreated controls (Figure 4B). This indicates that $P i$ prevents $V d$-induced stomata closure. These results demonstrate that stomatal closure correlates nicely with the amount of total chlorophyll.
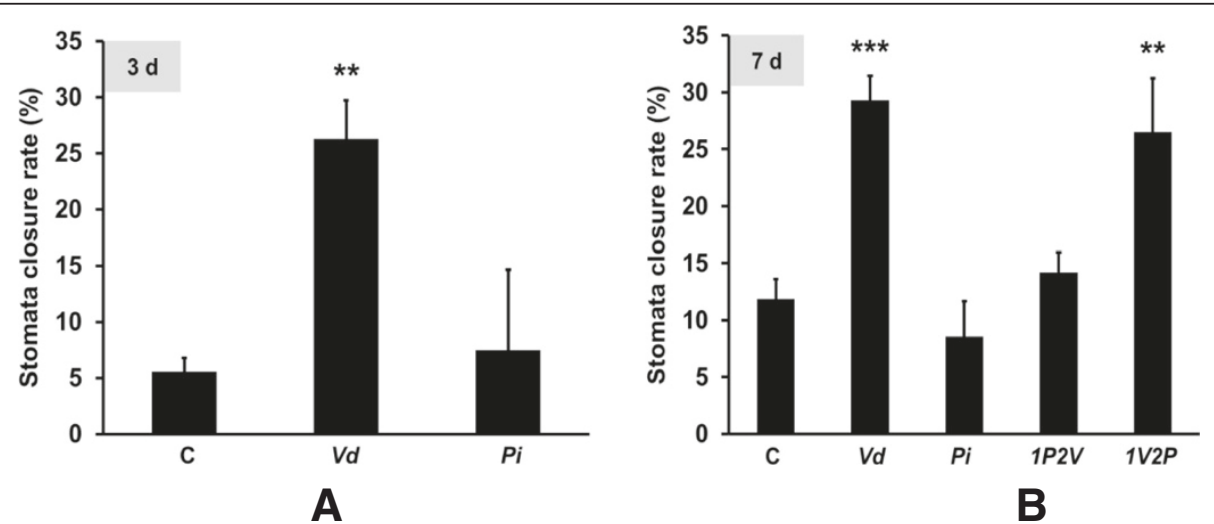

Figure 4 Stomata closure rate in leaves after 3 (A) and 7 (B) days. The data are based on 3 independent experiments with 16 seedlings each. Bars represent SDs. Asterisks indicate significant differences to the untreated control, as determined by Student's t-test $\left({ }^{*} P \leq 0.05\right.$; ${ }^{*} P \leq 0.01$; *** $P \leq 0.001)$ 


\section{$P i$ represses $V d$-induced genes in shoots}

$V d$ induces defense gene expression in shoots. After $1 \mathrm{~d}$, the mRNA levels for $P R 1$ and $P R 2$ representing SAinducible genes and PDF1.2 for the JA/ET pathway, ERF1 and VSP2 for ET pathway were upregulated in the leaves of $V d$-exposed seedlings. Except for $P R 2$, none of the other genes responded to $P i$ exposure (Figure 5). After 14 $\mathrm{d}, V d$-exposed seedlings showed an even stronger upregulation of the defense genes in the leaves (Figure 5). Pretreatment of the seedlings with $P i$ prior to $V d$ infection resulted in the repression of defense gene expression compared to seedlings which were not pretreated with $P i$. This provides additional evidence for the protective function of $P i$ against $V d$ infection. Furthermore, plant glutamate receptor-like (GLR) genes, GLR2.4, GLR2.5 and GLR3.3 code for putative $\mathrm{Ca}^{2+}$ transporters and are involved in defense responses [42-44]. We observed that GLR2.4 (but not GLR2.5 and GLR3.3) was upregulated in the leaves of $V d$-exposed seedlings and repressed in the leaves of seedlings which were pretreated with $P i$ prior to $V d$ exposure (Figure 5 and Additional file 1: Figure S2). RabGAP22 is required for defense to $V$. longisporum and contributes to stomata immunity [22]. For $V d$, RabGAP11 is upregulated after exposure to $V d$ and significantly repressed in seedlings which were pretreated with $P i$ (Figure 5).

\section{Pi strongly represses $V d$-induced phytohormone accumulation in shoots}

The phytohormones JA, JA-Ile, OPDA, SA, ABA and ET are crucial for the activation of defense responses. Figure 6 demonstrates that these phytohormones accumulated after $V d$ infection in the shoots of Arabidopsis seedlings. The phytohormone levels were also high in the $1 \mathrm{~V} 2 \mathrm{P}$ samples, while in all other cases [Control $(\mathrm{C}), \mathrm{Pi}, 1 \mathrm{P} 2 \mathrm{~V}$ ], they showed significantly lower levels. Thus, $\mathrm{Vd}$-induced phytohormone accumulation is repressed if the roots are colonized by $P i$ prior to their exposure to $V d$. Interestingly, application of $P i$ to roots which were already exposed to $V d$ did not repress the accumulation of the phytohormones in the shoots.

\section{Pi inhibits $V d$ propagation and microsclerotia formation}

Quantification of the amount of $V d$ DNA demonstrated that $\mathrm{Vd}$ and $1 \mathrm{~V} 2 \mathrm{P}$ seedlings contain twice as much pathogen DNA than $1 P 2 V$ seedlings in both roots (Figure 7A and $\mathrm{D}$ ) and shoots (Figure $7 \mathrm{~B}$ and $\mathrm{E}$ ). Interestingly, the amount of $P i$ DNA in the roots is identical in all $P i$-treated samples and not affected by a pretreatment with $V d$ (Figure $7 \mathrm{C}$ and F). Furthermore, microscopic analysis demonstrated that the number of microsclerotia was strongly reduced in root tissue pretreated with $\mathrm{Pi}$ (Figure 8). This demonstrates that $P i$ inhibits $V d$ propagation and microsclerotia formation in the roots, while $V d$ does not affect the propagation of $P i$ in Arabidopsis roots.

\section{Long-term experiments confirmed the results obtained for seedlings}

In order to study long term interaction, the seedlings were grown according to the 5 regimes on Petri dishes for 10 days before transferred to sterile vermiculite for additional 14 days. All (C) seedlings and those exposed to $\mathrm{Pi}(\mathrm{Pi})$ were alive. Exposure of $\mathrm{Pi}$-pretreated plants to $V d$ resulted in $\sim 20 \%$ loss of the plants. However $80 \%$ of the plants, which were either exposed to $V d$ alone or first to $V d$ followed by $P i$, died (Figure 9A). Furthermore, we measured the fresh weights of the seedlings which survived the treatments. Plants exposed to Pi alone showed a $\sim 30 \%$ increase in the fresh weight. The fresh weights of $1 P 2 \mathrm{~V}$ plants were comparable to those not exposed to any fungus. $V d$ - and $1 V 2 P$-treated seedlings showed significantly decreased fresh weights compared to all other treatments (Figure 9B). Finally, the $V d$ DNA amount in both shoots and roots was lower in $1 P 2 V$-treated plants compared to those treated with $V d$ alone or first with $V d$ followed by $P i(1 V 2 P)$ (Figure 9C). Comparable to the results obtained with seedlings in Petri dishes (Figure 7), the Pi DNA content was the same in all $P i$-treated roots (Figure 9C). This confirms that $P i$ inhibits $V d$ growth, but not vice versa.

EIN3 is required for full susceptibility of Arabidopsis to $V d$ The strong upregulation of the phytohormone levels in the leaves of seedlings grown in the presence of $V d$ was further investigated for ET. Pantelides et al. [11] have shown that ET perception via ETR1 is required for $V d$ infection in Arabidopsis. We observed a strong requirement of EIN3 for $V d$-induced disease development in Arabidopsis leaves. ein3 seedlings which were exposed to $V d$ alone or were first treated with $V d$ before application of $\mathrm{Pi}$ perform better than wild-type seedlings (Figure 10A, $\mathrm{B}$ and Additional file 1: Figure S3). Interestingly, the ET level in ein3 seedlings is much higher than in wild-type seedlings, even in the absence of $V d$. Exposure of the seedlings to $V d$ stimulate ET accumulation even further (Figure 10C and Additional file 1: Figure S4). This suggests that ein 3 seedlings try to compensate the lack of EIN3-induced genes by further stimulating ET biosynthesis, in particular after $V d$ infection. Taken together, these data demonstrate that EIN3-induced genes are required for pathogenicity of $V d$.

\section{$V d$ induces $\left[\mathrm{Ca}^{2+}\right]_{\text {cyt }}$ elevation in WT roots, but not in roots of a $\mathrm{Ca}^{2+}$ response mutant}

Pathogen-associated molecular pattern-triggered immunity is often initiated by $\left[\mathrm{Ca}^{2+}\right]_{\text {cyt }}$ elevation, which can be induced by exudated compounds from pathogenic fungi [cf. [45] and ref. therein]. Since the putative plasma membrane-localized $\mathrm{Ca}^{2+}$-transporter gene GLR2.4 was upregulated by $V d$, we tested whether exudated compounds 


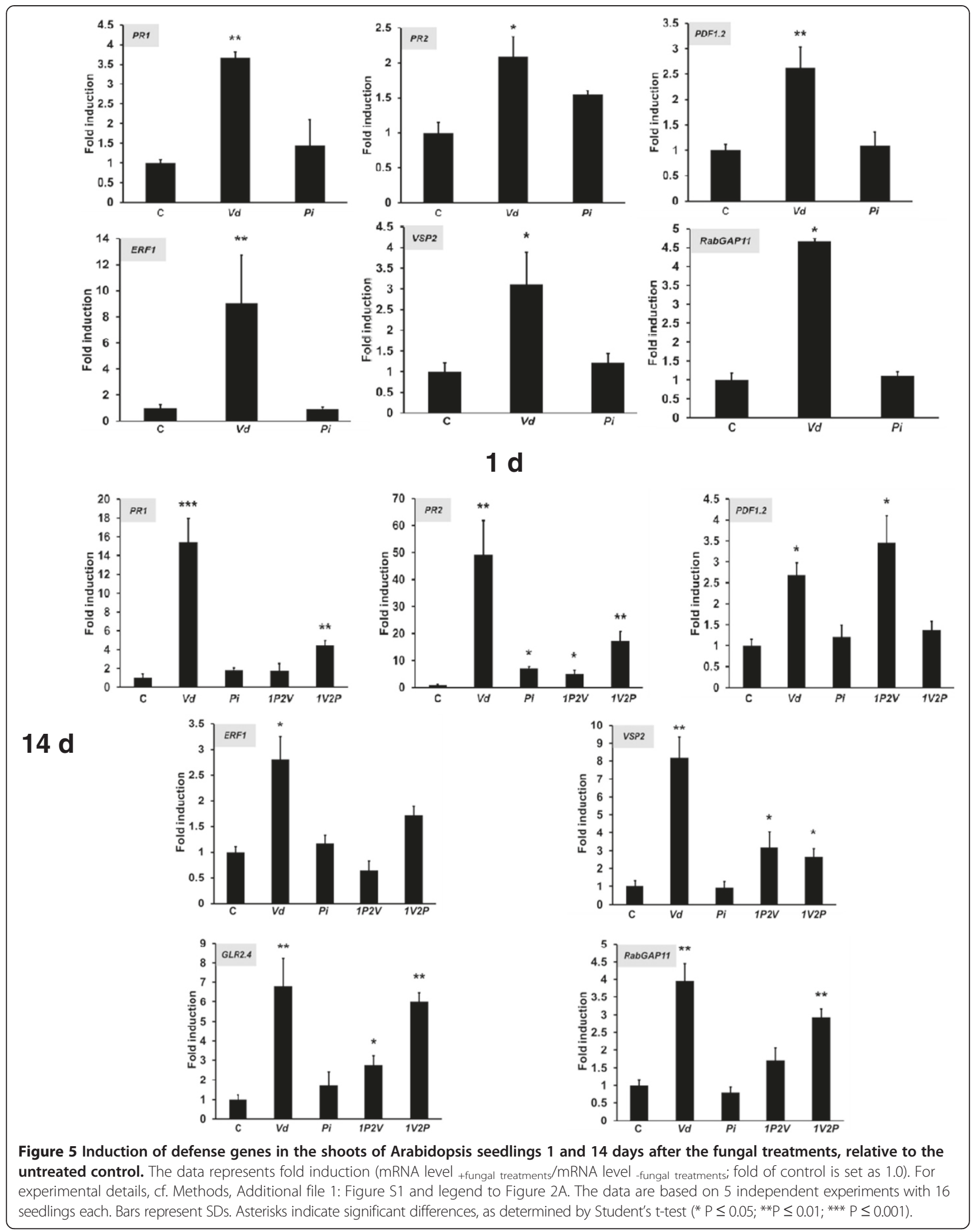



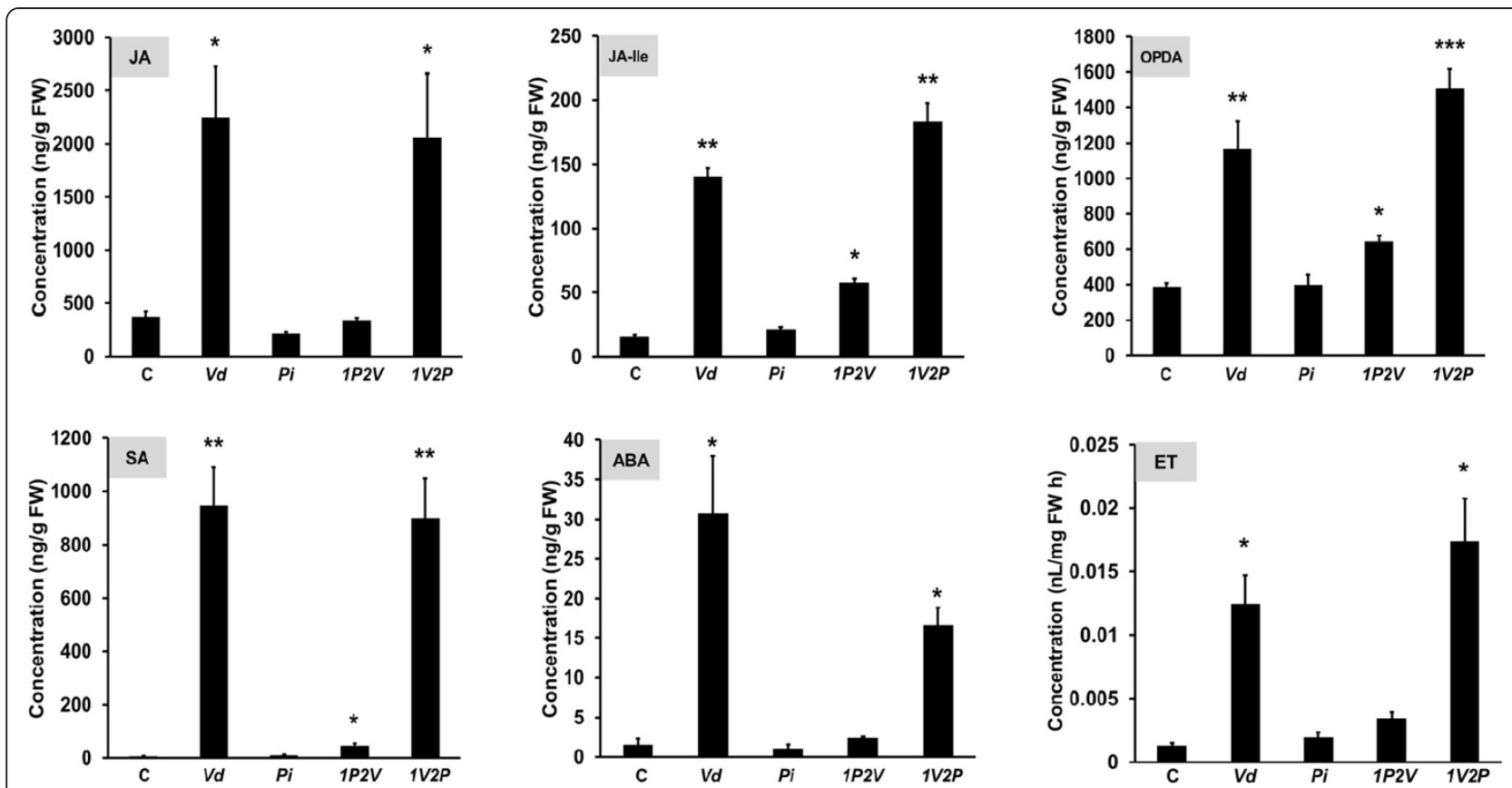

Figure 6 Phytohormone levels in the shoots 21 days after the different fungal treatments. For experimental details, cf. Methods, Additional file 1: Figure S1, and legend to Figure 2A. The data are based on 3 independent experiments with 12 seedlings each. Bars represent SDs. Asterisks indicate significant differences, as determined by Student's t-test ( $P \leq 0.05$; ${ }^{* *} P \leq 0.01$; ${ }^{* *} P \leq 0.001$ ).

from $\mathrm{Vd}$ can induce $\left[\mathrm{Ca}^{2+}\right]_{\text {cyt }}$ elevation in roots. An exudate preparation from the mycelium was applied to the roots of transgenic pMAQ2 Arabidopsis lines expressing the $\mathrm{Ca}^{2+-}$ sensor apoaequorin. Under resting conditions, $21 \mathrm{~d}$-old pMAQ2 lines gave $\left[\mathrm{Ca}^{2+}\right]_{\mathrm{cyt}}$ values of $70 \pm 0.6 \mathrm{nM}(n=16)$. A rapid and transient increase in the $\left[\mathrm{Ca}^{2+}\right]_{\mathrm{cyt}}$ concentration is observed $40 \mathrm{sec}$ after the application of $\mathrm{Vd}$ preparation (Figure 11A). Discharge at the end of the experiment demonstrates that less than $5 \%$ of the reconstituted aequorin was consumed after the stimuli, which ensures that the amount of aequorin in the sample is not limiting for the $\mathrm{Ca}^{2+}$ signal (data not shown). The $\left[\mathrm{Ca}^{2+}\right]_{\mathrm{cyt}}$ reached a peak of $\sim 400 \mathrm{nM}$ after 90 to $120 \mathrm{sec}$ (Figure 11A). Subsequently the $\mathrm{Ca}^{2+}$ levels steadily decreased. No $\left[\mathrm{Ca}^{2+}\right]_{\mathrm{cyt}}$ elevation is observed with the PBS buffer treatment (Figure 11A). The magnitude of the $\left[\mathrm{Ca}^{2+}\right]_{\text {cyt }}$ response is dose-dependent (data not shown). Furthermore, an Arabidopsis cytoplasmic calcium elevation mutant1 (cycam1) which does not show $\left[\mathrm{Ca}^{2+}\right]_{\text {cyt }}$ elevation in response to exudate preparation from various pathogenic fungi [45] also failed to induce $\left[\mathrm{Ca}^{2+}\right]_{\text {cyt }}$ elevation in response to the $V d$ preparation (Figure 11B). This indicates that cycam1 is impaired in the response to exudate preparations from various pathogens. Furthermore, we crossed the apoaeqorin gene into the glr2.4, glr2.5 and glr3.3 knock-out background. Figure $11 \mathrm{~B}$ demonstrates that the $V d$ exudate preparation induced $\left[\mathrm{Ca}^{2+}\right]_{\text {cyt }}$ elevation in the knock-out backgrounds, indicating that these putative plasma membrane-localized transporters do not participate in the $\mathrm{Ca}^{2+}$ uptake from the extracellular space, although the gene GLR2.4 was upregulated in $V d$-infected seedlings (Figure 5).

To investigate whether $\left[\mathrm{Ca}^{2+}\right]_{\text {cyt }}$ elevation is required for disease development, cycam 1 was infected with $V d$ and the development of the mutant seedlings was compared to that of the WT seedlings. No obvious difference of the disease symptoms in the aerial parts could be detected, which suggests that $\left[\mathrm{Ca}^{2+}\right]_{\mathrm{cyt}}$ elevation is not essential for $V d$ propagation (Additional file 1: Figure S6).

\section{Discussion}

Our data demonstrate that $P i$ is a very efficient biocontrol agent for $V d$ wilt in Arabidopsis. Pi restricts $V d$ growth both on agar plates (Figure 1) and in Arabidopsis roots, in particular when they were first colonized by $P i$ prior to infection with $V d$ (Figure 7). Molecular and biochemical analyses demonstrate that the reduced growth rate of $V d$ in $P i$-pretreated Arabidopsis roots retards defense gene expression (Figure 5), the accumulation of defense-related phytohormones (Figure 6) and stomata closure (Figure 4). The performance of the seedlings is significantly better (Figure 2 ) and this also continues after shifting the seedlings to vermiculite for a longer period of time (Figure 9). $P i$ not only inhibits growth of $V d$ mycelia in Arabidopsis roots, but also prevents the spread of the pathogen to the aerial parts of the plant (Figure 7). Furthermore, microsclerotia formation is strongly reduced (Figure 8). Previously, several soil-borne bacteria have been identified as biocontrol agents for Verticillium wilt 

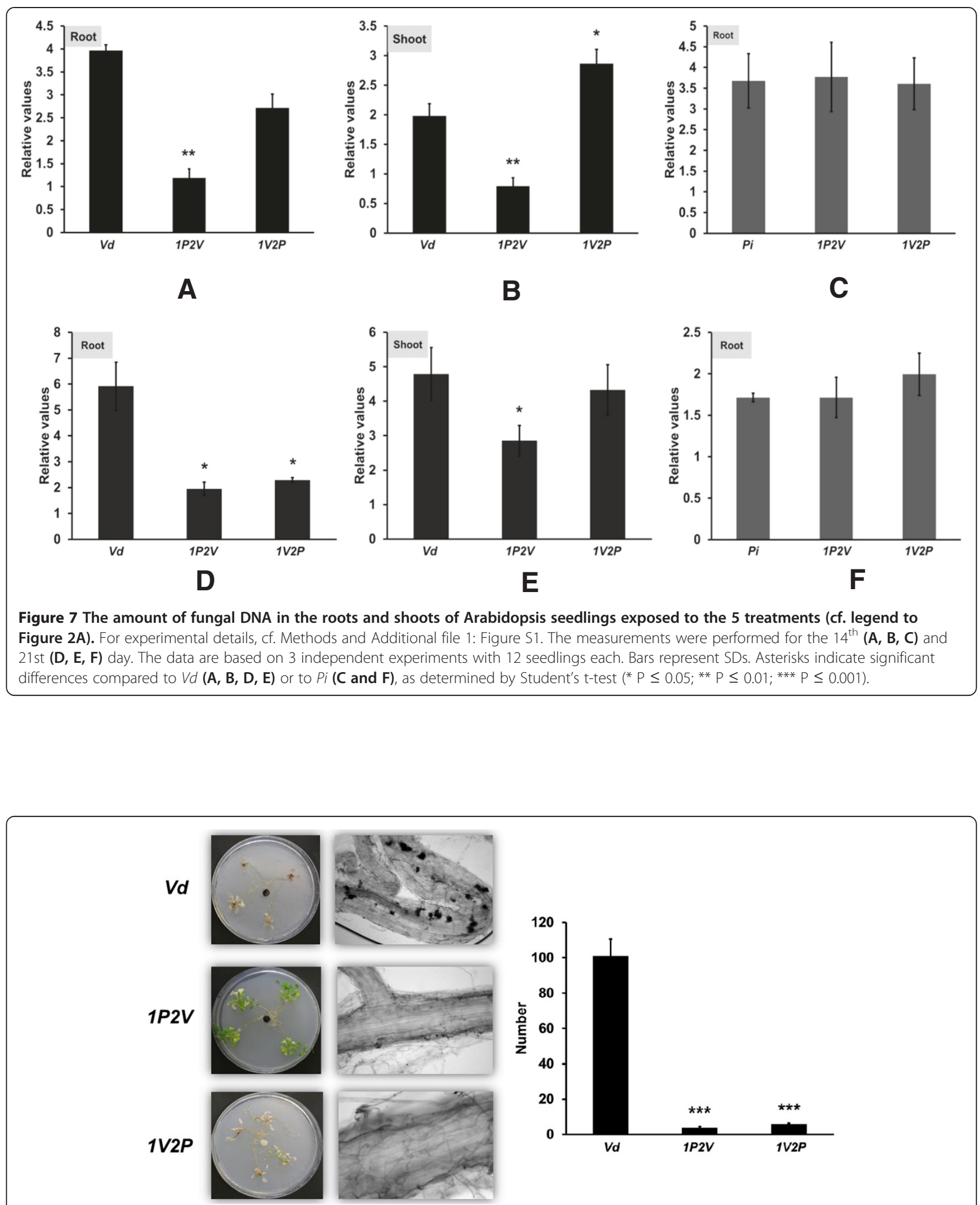

Figure $8 \mathrm{Pi}$ inhibits the formation of $V d$ micosclerotia in roots, irrespective of whether the roots were first exposed to $P i(1 P 2 V$ or first to $\boldsymbol{V} \boldsymbol{d}(\mathbf{V} \mathbf{2} \boldsymbol{P})$. The analysis was performed 21 days after infection. Left: microscopy of root sections with microslerotia (black spots). Right: Quantification of the number of microsclerotia. The data are based on 3 independent experiments with 12 seedlings each. Bars represent SDs. Asterisks indicate significant differences to $V d$, as determined by Student's t-test (* $P \leq 0.05$; ${ }^{* *} P \leq 0.01 ;{ }^{* *} P \leq 0.001$ ). 


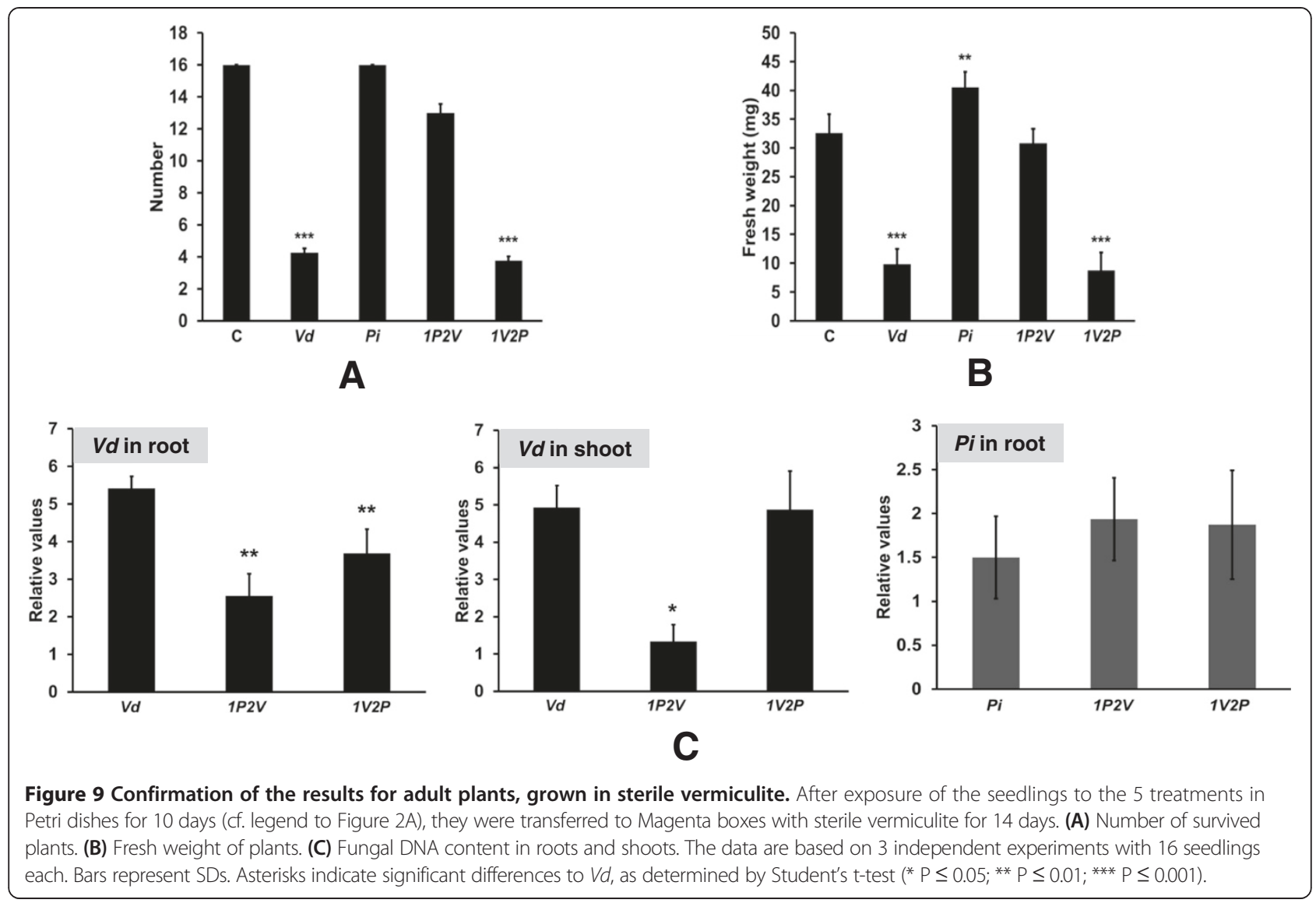

[29,46-48]. Vd can induce antimicrobial metabolites such as rutin in potato [49] or pathogenesis-related proteins in Arabidopsis [12] which participates in pathogen resistance. Prieto et al. [50] demonstrated that root hair colonization plays an important role in Pseudomonas spp.-mediated biocontrol activity against Verticillium wilt in olive roots. Furthermore, the Bacillus subtilis strain NCD-2 functions as a biocontrol agent against cotton Verticillium wilt, and the cotton PhoR/PhoP, two component regulatory systems, were involved in the biocontrol capability of the bacterium [51]. Also quorum sensing is involved in the biocontrol activity of Serratia plymuthica against $V d$ [52]. Moderate drought influences the effect of arbuscular mycorrhizal fungi as biocontrol agents against Verticillium-induced wilt in pepper [53]. It appears that quite different mechanisms control the fungal spread, probably because of the complicated lifestyle of the pathogen which allows microbial interference at different levels and in different plant tissues.

An increasing number of genes were recently identified to be involved in establishing partial resistance to Verticillium wilts (cf. Background). Pathogen attack including root colonization by $V d$ is associated with stomata closure as one of the first line of plant defense (Figure 4). RabGAP22 is required for defense against
$V$. longisporum and contributes to stomatal immunity [20]. RabGAP11 gene is upregulated by $V d$ and repressed by $P i$ (Figure 5). Finally, defensins play a role in the plant defense against $V d$ [19].

Control of microsclerotia formation is crucial for preventing Verticillium spread in nature and agriculture. Our data demonstrate that $P i$ is quite efficient in restricting microsclerotia formation in Arabidopsis roots (Figure 8), presumable because the pathogen cannot grow fast enough in the presence of $\mathrm{Pi}$. Microsclerotia formation is also suppressed by Verticillium itself, i.e. by the fungal transcription activator of adhesion Vta2, and fungi impaired in Vta2 are unable to colonize plants and induces disease symptoms [21]. Taken together, $P i$ restricts $V d$ growth as well as hyphal and microslerotia propagation, which - in turn - causes that the plant defense processes get activated at a lower level compared to $\mathrm{Vd}$ treatments which might depend on $\mathrm{Pi}$ plant- $V d$ interaction-pattern and the attack strategy of $V d$. This is not only important for better performance of individual plants, but has also severe long-term consequences for the control of the $V d$ spread via microsclerotia in ecosystems and agricultural areas.

GRL homologs are associated with $\mathrm{Ca}^{2+}$ influx through the plasma membrane. Figure 5 demonstrates that the 


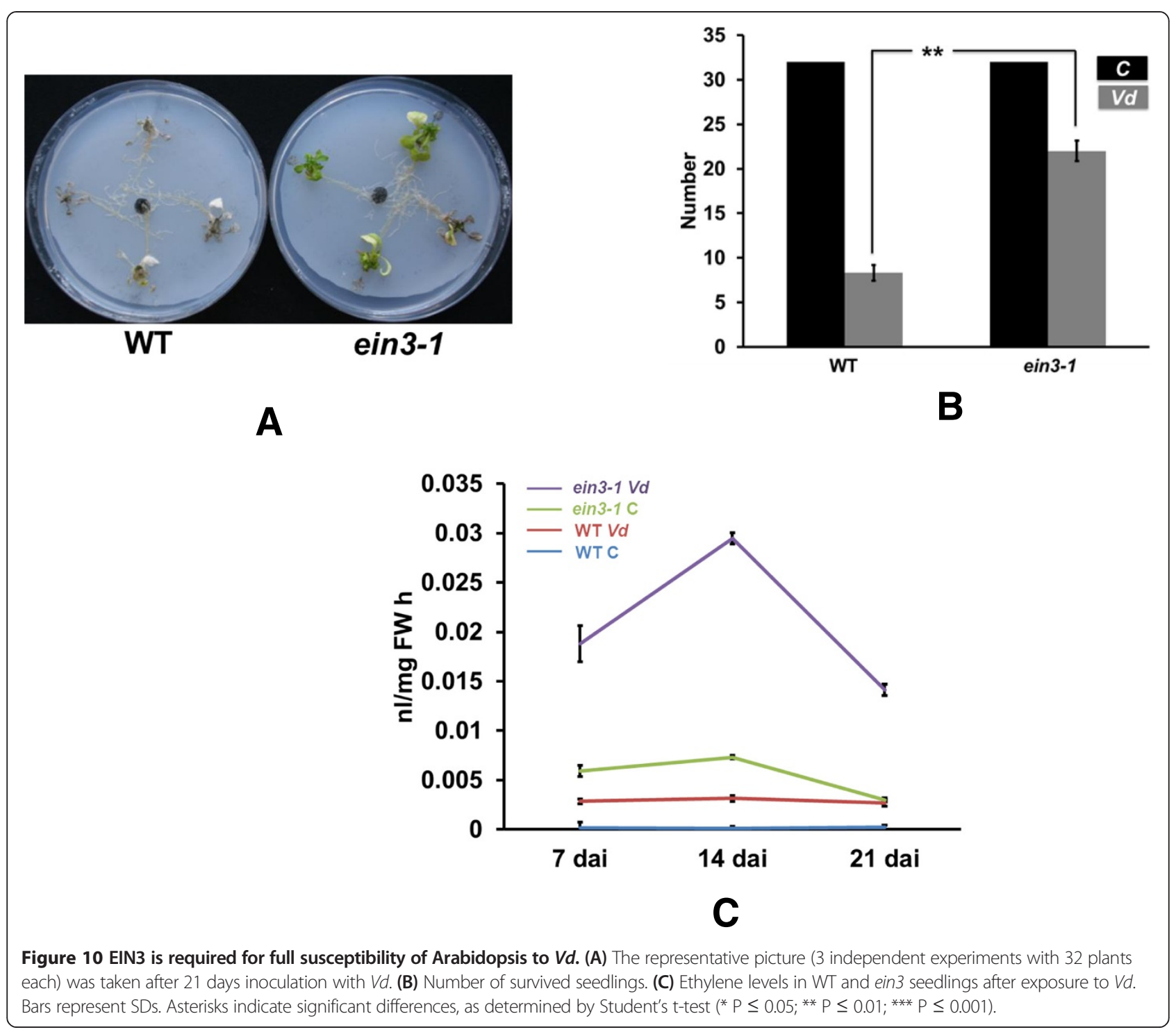

mRNA level for GLR2.4 is upregulated in the leaves of $V d$-infected Arabidopsis seedlings and these responses are restricted by a pretreatment of the seedlings with $P i$. GLR3.3 is involved in plant defense and resistance to Hyaloperonospora arabidopsidis [44]. The protein also mediates glutathione-triggered $\left[\mathrm{Ca}^{2+}\right]_{\mathrm{cyt}}$ transients, transcriptional changes, and innate immunity responses in Arabidopsis [54]. GLR2.5 is upregulated in Arabidopsis cell cultures upon wounding [43] and GLR2.4 is induced by nematodes in Arabidopsis roots [42]. GLR2.4, also called AUGMIN subunit 8, is a microtubule plus-end binding protein that promotes microtubule reorientation in hypocotyls [55,56]. Microtubules and microtubule orientation are important for plant defense and immunity $[56,57]$ and also involved in $V d$-Arabidopsis interaction. $\mathrm{Hu}$ et al. [18] demonstrated that histone $\mathrm{H} 2 \mathrm{~B}$ monoubiquitination is involved in regulating the dynamics of microtubules during the defense response to $V d$ toxins in Arabidopsis. Yuan et al. [58] showed that $V d$ toxins disrupted microfilaments and microtubules in Arabidopsis suspension-cultured cells. Figure $11 \mathrm{~A}$ shows that exudate compounds from $V d$ induces $\left[\mathrm{Ca}^{2+}\right]_{\mathrm{cyt}}$ elevation in Arabidopsis roots. In order to test whether the $\left[\mathrm{Ca}^{2+}\right]_{\text {cyt }}$ elevation is mediated by one of the three GLRs, we generated transgenic glr3.3, glr2.5 and glr2.4 knock-out lines in the apoaequorin background and found that the $\left[\mathrm{Ca}^{2+}\right]_{\text {cyt }}$ response is not controlled by the three GLRs (Figure 11B), although the mRNA level of GLR2.4 is upregulated upon $V d$ infection (Figure 5). This suggests that GLRs have different functions in the $V d$-Arabidopsis interaction. However, an ethylmethansulfonate-induced Arabidopsis mutant named cycam 1 which is unable to 

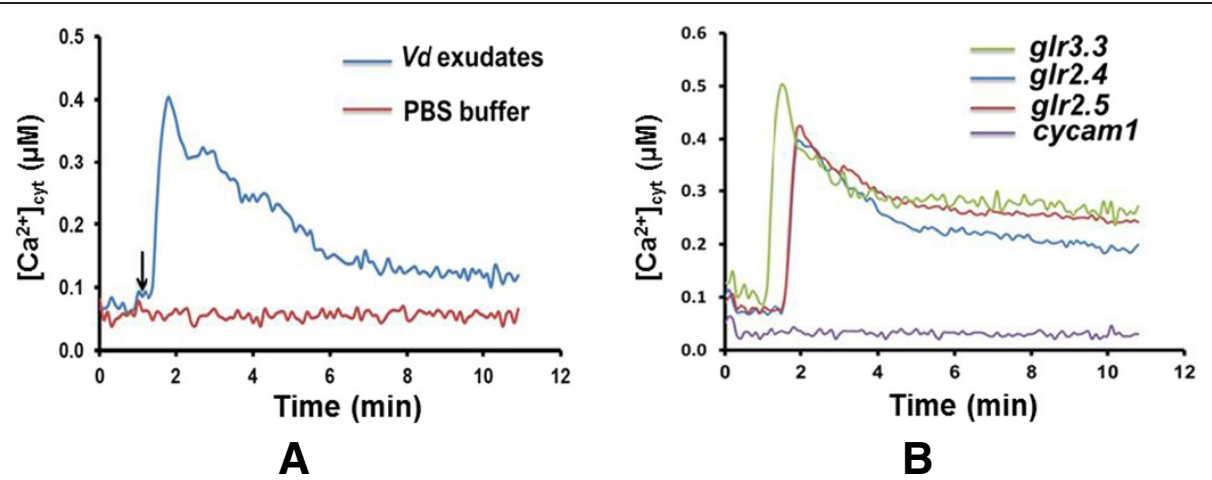

Figure $11 \mathrm{Vd}$ exudate preparation induces $\left[\mathrm{Ca}^{2+}\right]_{\mathrm{cyt}}$ elevation in $\mathrm{A}$. thaliana seedlings expressing cytosolic aequorin. (A) Roots of 21-day old PMAQ2 in Col-0 seedlings were dissected and incubated overnight in $7.5 \mu \mathrm{M}$ coelenterezine. The roots were challenged with $50 \mu \mathrm{l}$ of the $\mathrm{Vd}$ preparations. $\left[\mathrm{Ca}^{2+}\right]_{\mathrm{cyt}}$ level was calculated from the relative light unit (RLU) at $5 \mathrm{~s}$ integration time for $10 \mathrm{~min}$. The arrow indicates the time (60 s) of addition of the stimuli/PBS buffer. For all experiments, $10 \mathrm{mM}$ phosphate buffer (PBS, pH 7.0) was used as control and gave background readings. All curves and values represent average of five independent experiments with eight replications in each experiment. (B) Vd exudate preparation does not induce $\left[\mathrm{Ca}^{2+}\right]_{\text {cyt }}$ elevation in the cycam1 mutant, but induces $\left[\mathrm{Ca}^{2+}\right]_{\text {cyt }}$ elevation in pMAQ2 lines in the g/r2.4, g/r2.5 and g/r3.3 background.

induce $\left[\mathrm{Ca}^{2+}\right]_{\text {cyt }}$ elevation in response to exudate preparations from Alternaria brassicae, Rhizoctonia solani, Phytophthora parasitica var. nicotianae and Agrobacterium tumefaciens [45] did not respond to the $V d$ exudate preparation (Figure 11B). This demonstrates that at least one of the $V d$-induced signaling events leading the opening of $\mathrm{Ca}^{2+}$ channels or the channels themselves are identical to those responding to exudate preparations from other pathogens [45]. However, the reduced $\mathrm{Ca}^{2+}$ response in the cycam 1 mutant does not affect the disease development. It remains to be determined which is the active compound inducing the $\left[\mathrm{Ca}^{2+}\right]_{\mathrm{cyt}}$ response in Arabidopsis roots, and what is the mutated gene in the cycam 1 mutant.

Several exudated compounds have been postulated to induce pathogenicity in plants. Klosterman et al. [3] proposed that based on the sequence information of Verticillium species, pathogenicity may be caused by a cocktail of different compounds and elicitors with different functions in the complex pathogenicity procedure. A Verticillium crude toxin preparation has been often used, although the exact composition of this preparation and the role of the individual compounds are not clear. For instance, recently Yao et al. [59] have demonstrated that the $V d$ toxin preparation stimulates nitric oxide production in Arabidopsis which serves as a signaling intermediate downstream of $\mathrm{H}_{2} \mathrm{O}_{2}$ to modulate dynamic microtubule cytoskeleton. This may link the $V d$ toxin function again to GLR2.4, who's mRNA level is upregulated after $V d$ infection (Figure 5). Wang et al. [60] reported on the purification and characterization of a novel hypersensitive-like response-inducible protein elicitor named PevD1 from $V d$ that induces resistance responses in tobacco. The relationship of the bioactive compound that induces the $\left[\mathrm{Ca}^{2+}\right]_{\text {cyt }}$ response to the toxins which induce disease responses needs to be investigated.

Interestingly, we did not observe a linear relationship between the propagation of $V d$ in the seedlings and the accumulation of defense-related phytohormone levels. For instance, the phytohormone levels were always high when the seedlings were exposed to $V d$, irrespective of whether they were exposed to $V d$ alone, pretreated with $\mathrm{Pi}$ or first with $\mathrm{Vd}$ followed by $\mathrm{Pi}$ (Figure 6), although, growth of $V d$ was strongly reduced by the $P i$ pretreatment (Figure 1). This suggests that even low infection rates of $V d$ are sufficient to stimulate the accumulation of the defense hormones. This might be a precaution, although propagation of $V d$ is inhibited when the roots were pretreated with $\mathrm{Pi}$.

Various reports showed the involvement of plant hormones in the control of Verticillium growth in Arabidopsis. Stabilization of cytokinin levels enhances Arabidopsis resistance against $V$. longisporum [17]. The fungus also requires JA-dependent COI1 function in roots to elicit disease symptoms in Arabidopsis shoots [15]. Ethylene perception via the receptor ETR1 is required for $V d$ infection in Arabidopsis [11]. Enhanced resistance of etr1-1 plants, but not of SA-, JA- or other ET-deficient mutants against $V d$ infection indicate a crucial role of ETR1 in defense against this pathogen. We observed a particularly striking resistance of the Arabidopsis ein3 mutant against $V d$ infection in vivo and in vitro (Additional file 1: Figure S5). This is consistent with the reports by Pantelides et al. [11] for etr1, although they did not observe a significant role of EIN3 in their studies. Our data demonstrate that EIN3 plays an important role in 
pathogenicity and will provide an important tool to identify EIN3-regulated genes which are required for $V d$ disease development. Furthermore, the ET level in the ein3 mutant exposed to $V d$ is much higher compared to $V d$-exposed WT seedlings (Figure 10C). This suggests a feedback loop by which the lack of EIN3-induced defense responses in the ein 3 mutant results in an additional stimulation of ET synthesis.

\section{Conclusions}

In summary, our data demonstrate that $P i$ is a very efficient biocontrol agent for $V d$. This is mainly caused by the restriction of $V d$ growth in the presence of $P i$. There appears to be additional mechanisms which prevent pathogenicity of $V d$ in the presence of $P i$. For instance, the phytohormone levels accumulate to comparable levels in $V d$ and $1 P 2 V$ seedlings, although $V d$ propagation is restricted in the presence of $P i$ (Figure 1). Since $\mathrm{Pi}$ pretreatment severely reduces defense gene expression in spite of a comparable phytohormone level in these tissues, additional signals from $\mathrm{Pi}$ must participate in the regulation of the immune response against $V d$.

\section{Methods}

\section{Growth conditions of seedlings and fungi}

A. thaliana wild-type (ecotype Columbia-0) seeds, seeds of the glr2.4, glr2.5, glr3.3 and ein 3 mutants as well as of cycam 1 mutant [45] were surface-sterilized and placed on Petri dishes with MS media [61]. After cold treatment at $4^{\circ} \mathrm{C}$ for $48 \mathrm{~h}$, plates were incubated for 11 days at $22^{\circ} \mathrm{C}$ under long day conditions $(16 \mathrm{~h}$ light $/ 8 \mathrm{~h}$ dark; $\left.80 \mu \mathrm{mol} \mathrm{m}{ }^{-2} \mathrm{sec}^{-1}\right)$. $P i$ was grown for 3-4 weeks on KM medium as described previously [62]. For detailed information see Section A and B in Johnson et al. [63]. Vd (FSU-343, Jena Microbial Resource Center, Germany) was grown for 2-3 weeks on Potato Dextrose Agar (PDA) medium [64].

\section{Co-cultivation assays}

For co-cultivation assays 13 day-old A. thaliana seedlings of equal size were used. Co-cultivation of $A$. thaliana and the fungi $P i$ and/or $V d$ was performed under in vitro culture conditions on a nylon membrane on PNM media as described by Johnson et al. ([63], Section C1 - Method 1) with a few modifications. $V d$ was grown for 12 days and $P i$ for 10 days on the membrane on top of PNM medium in Petri dishes. 13-day old Arabidopsis seedlings were then transferred to the $P i$ or $V d$ plates, or mock-treated (no fungal mycelium; C). For the shifting experiments, the seedlings were transferred to plates with the other fungus after 4 days (from $V d$ to $P i$ or vice-versa). Including the $(C)$, five different treatments were compared: (1) Arabidopsis seedlings grown without $P i$ or $V d(C)$; (2) without $P i$ and with $V d(V d)$; (3) with
$P i$ and without $V d(P i)$; (4) with $P i$ for 4 days before transfer to $V d$ plates (1P2V) and (5) with $V d$ for 4 days before transfer to $\mathrm{Pi}$ plates $(1 \mathrm{~V} 2 \mathrm{P})$. The seedlings were harvested between 1 and 21 days after exposure to the first fungus (or mock-treatment) for further analysis. A time scheme is shown in Additional file 1: Figure S1. The light intensity $\left(80 \mu \mathrm{mol} \mathrm{m} \mathrm{m}^{-2} \mathrm{~s}^{-1}\right)$ was checked weekly. Shoots and roots were harvested separately for DNA and RNA analyses.

\section{Long term co-cultivation in sterile vermiculite}

$30 \mathrm{~g}$ vermiculite was placed into one Magenta box (Sigma-Aldrich, Germany) and autoclaved at $121^{\circ} \mathrm{C}$ for $30 \mathrm{~min}$. After the addition of $40 \mathrm{ml}$ of sterile liquid PNM medium, Arabidopsis seedlings grown in Petri dishes for 10 days were transferred to the sterile vermiculite boxes ( 1 plant per box). For each treatment, 16 seedlings were analyzed. After 10 days, the number of survived plants, their biomass and fungal DNA content were determined.

\section{Gene expression analysis}

RNA was isolated from shoots and reverse-transcribed for Real-time quantitative PCR analysis, using an iCycler iQ Real-time PCR detection system and iCycler software version 2.2 (Bio-Rad). Total RNA was isolated from 5 independent biological experiments of Arabidopsis shoots. cDNA was synthesized using the Omniscript cDNA synthesis kit (QIAGEN) using $1 \mu \mathrm{g}$ RNA. For the amplification of the RT-PCR products, iQ SYBR Green Supermix (Bio-Rad) was used according to the manufacturer's protocol in a final volume of $20 \mu \mathrm{l}$. The iCycler was programmed to $95^{\circ} \mathrm{C} 3 \mathrm{~min}, 40 \times\left(95^{\circ} \mathrm{C} 30 \mathrm{sec}, 57^{\circ} \mathrm{C} 15 \mathrm{sec}\right.$, $\left.72^{\circ} \mathrm{C} 30 \mathrm{sec}\right), 72^{\circ} \mathrm{C} 10 \mathrm{~min}$, followed by a melting curve program $55^{\circ} \mathrm{C}$ to $95^{\circ} \mathrm{C}$ in increasing steps of $0.5^{\circ} \mathrm{C}$. All reactions were performed in triplicate. The mRNA levels for each cDNA probe were normalized with respect to the glycerin-aldehyde-3-phosphate dehydrogenase (GAPDH) mRNA level. The primer pairs are given in Additional file 1: Table S1.

\section{Quantification of fungal DNAs by PCR}

Genomic DNA extraction was conducted with DNeasy Plant Mini Kit. 12.5 ng DNA was taken for PCR template. The reactions were performed with gene-specific primers, as given in Additional file 1: Table S1. For details see Camehl et al. [65].

\section{Dual culture of $P i$ and $V d$}

Dual culture of $P i$ and $V d$ on agar plates was performed as described by Johnson et al. [66]. A Pi plug with $5 \mathrm{~mm}$ diameter was placed at one end of a PDA plate and a $V d$ plug of the same size at the other end of the plate. The plates were incubated at $22-24^{\circ} \mathrm{C}$ in dark and $75 \%$ 
relative humidity. Photos were taken after 3 weeks of co-cultivation.

\section{Percentage disease index (PDI) calculation}

Disease index was calculated with the following formula:

$$
\mathrm{PDI}=\frac{\mathrm{n}_{1} \mathrm{x}_{1}+\mathrm{n}_{2} \mathrm{x}_{2}+\mathrm{n}_{3} \mathrm{x}_{3}+\mathrm{n}_{4} \mathrm{x}_{4}+\mathrm{n}_{5} \mathrm{x}_{5}}{\text { Total number of leaves observed } \times \text { maximum grade }} \times 100
$$

$\mathrm{n}_{1-5}=$ number of affected leaves of the respective disease.

Severity grade (0-5), $\mathrm{x}_{1-5}=$ disease severity grade based on the percentage of affected leaf area. 1, $1 \% \leq x \leq 10 \% ; 2$, $10 \%<x \leq 20 \% ; 3,20 \%<x \leq 30 \% ; 4,30 \%<x \leq 40 \% ; 5, x>$ 40\%; $\times 100$ : calculated in percentage scale. Disease severity was estimated on the basis of affected leaf area. 1-5 disease severity grades were described by Naik and Lakkund $[67,68]$.

Quantification of jasmonic acid (JA), JA-isoleucine (JA-lle), abscisic acid (ABA), salicylic acid (SA), oxophytodinoic acid (OPDA) and ethylene (ET)

Independent samples of $250 \mathrm{mg}$ shoot material were collected from each treatment. Phytohormone extractions (JA, JA-Ile, ABA, SA and OPDA) were performed by adding $1 \mathrm{ml}$ ethyl-acetate containing $60 \mathrm{ng}$ of $\mathrm{D}_{2}$-JA and $40 \mathrm{ng}$ of $\mathrm{D}_{6}$-ABA, $\mathrm{D}_{4}$-SA and JA- ${ }^{13} \mathrm{C}_{6}$-Ile (OPDA has the same internal standerd as JA) to $100 \mathrm{mg}$ ground tissues. All samples were then vortexed for $10 \mathrm{~min}$ and centrifuged at $13,000 \mathrm{rpm}$ for $20 \mathrm{~min}$ at $4^{\circ} \mathrm{C}$. The supernatants were collected and evaporated to dryness at $30^{\circ} \mathrm{C}$ using a vacuum concentrator. Residues were resuspended in $500 \mu \mathrm{l} \mathrm{MeOH}: \mathrm{H}_{2} \mathrm{O}(70: 30, \mathrm{v} / \mathrm{v})$ and centrifuged at $13,000 \mathrm{rpm}$ for $10 \mathrm{~min}$. The supernatants were collected and measured with the API 3200 LC-MS/MS system (Applied Biosystems, Framingham, USA) as previously described [69].

For ET measurements, $100 \mathrm{mg}$ shoot material from each treatment was collected into $4 \mathrm{ml}$ vials (Roth, Germany). After $4 \mathrm{~h}$ ET accumulation, the measurement was performed with the ETD-300 ethylene detector (Sensor Sense B.V., Nijmegen, The Netherlands).

Chlorophyll content was determined according to Yang et al. [70] and based on $g$ fresh weight.

\section{Quantification of microsclerotia}

Roots of Arabidopsis seedlings from the 3 treatments with $V d$ were harvested after 3 weeks of co-cultivation in Petri dishes and transferred to a microscopic glass slide with $80 \mu \mathrm{l}$ lactic acid/glycerol/ $\mathrm{H}_{2} \mathrm{O}$ (1:1:1). The number of the microsclerotia formed in the roots was calculated averagely per root visually under the light microscope (magnification: x200). The experiment was performed 3 times independently and for each treatment the roots of 12 seedlings were analysed.

\section{Cytoplasmic $\mathrm{Ca}^{2+}\left(\left[\mathrm{Ca}^{2+}\right]_{\mathrm{cyt}}\right)$ measurement}

Aequorin based luminescence measurements were performed using 21-day old individual wild-type (WT) plants and mutants grown in Hoagland medium [71]. WT aequorin (pMAQ2) plants served as control [72]. Mutants (glr2.4, glr2.5 and glr3.3) were crossed back to wild-type expressing aequorin. After 2 generation selection based on $\left[\mathrm{Ca}^{2+}\right]_{\text {cyt }}$ responses and RT-PCR of TDNA insertion examination, the homozygote seeds were used for the described experiments. Primers used for homozygosity tests are given in Additional file 1: Table S1. For $\left[\mathrm{Ca}^{2+}\right]_{\text {cyt }}$ measurements, approximately $70 \%$ of the roots per seedling was dissected and incubated overnight in $150 \mu \mathrm{l}$ of $7.5 \mu \mathrm{M}$ coelentrazine (P.J.K. GmbH, Germany) in the dark at $20^{\circ} \mathrm{C}$ in a 96 well plate (Thermo Fischer Scientific, Finland, cat. no. 9502887). Bioluminescence counts from roots were recorded as relative light units (RLU) with a microplate luminometer (Luminoskan Ascent, version 2.4, Thermo Electro Corporation, Finland).

\section{Preparation of exudates from mycelia of $V d$}

A $5 \mathrm{~mm} \mathrm{Vd}$ fungal plug was inoculated in Czapek's medium as described in Zhen et al. [73] and grown for 3 weeks. Then, the fungal culture was filtered through double layers of filter paper and the filtrate was centrifuged at $10,000 \mathrm{~g}$ for $30 \mathrm{~min}$ to remove the spores. The supernatant was dialyzed with a dialysis membrane (MWCO) (Spectra/Por ${ }^{\circ}$ Float-A-lyzer ${ }^{\circ}$ ) in $10 \mathrm{mM}$ phosphate buffer $\mathrm{pH} 7.0$ at $4^{\circ} \mathrm{C}$ for $24 \mathrm{~h}$. The dialyzed solution was frozen and lyophilized. The powder was dissolved in distilled water and the solution was filtered through a $0.45 \mu \mathrm{m}$ pore size Millipore filter (Roth, Germany). The resulting filtrate was used as exudate for further experiments.

\section{Statistics}

All statistical analyses were performed using Excel or SPSS 17.0 (SPSS Inc., Chicago, IL, USA) for ANOVA.

\section{Availability of supporting data}

All the supporting data are included as additional file.

\section{Additional file}

Additional file 1: Figure S1. Co-cultivation time scheme. The seeds were first kept at $4^{\circ} \mathrm{C}$ in the dark for 2 days and were then transferred to a light/dark cycle at $22^{\circ} \mathrm{C}$ for 9 days. These seedlings were used for the experiments, by either transferring them to a plate with $\mathrm{Vd}$ or Pi (or no fungus, control, C) at day 0 . The seedlings were harvested 10, 14 or 21 days later. In case of transfer from Vd to Pi or vice versa, the transfer occurred at day 4. Figure S2. Induction of GLR genes in shoots of Arabidopsis seedlings after 1 and 14 days. Figure S3. Phenotype of ein3-1 and WT after 21 days of co-cultivation following the 5 treatments described in Methods. Figure S4. ET content in shoots of ein3-1 seedlings after 3 weeks. Figure S5. Phenotypes of WT and ein3-1 after Vd spore inoculation in vivo and in vitro. 
Figure S6. Phenotype of WT and cycam 1 mutant 21 days after Vd inoculation. Table S1. Primer list for RT-PCR and PCR analysis.

\section{Abbreviations \\ Vd: Verticillium dahliae; Pi: Piriformospora indica; $\left[\mathrm{Ca}^{2+}\right]_{\mathrm{cyt}}$ : Cytosolic calcium; cycam 1: Cytosolic calcium elevation mutant 1; glr: Glutamate receptor mutants; ein3: Ethylene-insensitive3 mutant; JA: Jasmonic acid; JA-lle: Jasmonyl-isoleucine; ABA: Abscisic acid; SA: Salicylic acid; OPDA: Oxophytodinoic acid; ET: Ethylene; WT: Wild-type.}

\section{Competing interests}

The authors declare that they have no competing interests.

\section{Authors' contributions}

CS designed and carried out most of the experiments. YQS prepared the exudates from $V$. dahliae. KV helped for root microscopy and long term experiments in soil. $J \mathrm{~L}$ and SB did the phytohormone analysis. SD, K-WY, BL and ITB contributed to the discussion. CS, IS and RO wrote the article. RO supervised the research. All authors read and approved the final manuscript.

\section{Acknowledgements}

We like to thank Sarah Mußbach and Claudia Röppischer for their excellent technical assistance. Special thanks go to Dr. Justin Lee from Leibniz Institute of Plant Biochemistry, Halle, Germany, for providing ein3 mutant seeds and to Prof. Daguang Cai from University of Kiel, Germany, for providing Vd primers. C.S. was supported by the German Science Foundation and the German Exchange Program (DAAD). R.O. and K-W.Y. are supported by a travel exchange project (DAAD).

\section{Author details}

${ }^{1}$ Institute of Plant Physiology, Friedrich-Schiller-University Jena, Dornburger Str. 159, 07743 Jena, Germany. ${ }^{2}$ Max Planck Institute for Chemical Ecology, Hans-Knöll-Str. 8, D-07745 Jena, Germany. ${ }^{3}$ College of Life Sciences, Yangtze University, Jingzhou, China. ${ }^{4}$ Institute of Plant Biology, National Taiwan University, Taipei, Taiwan. ${ }^{5}$ Institute of Biotechnology, Zhejiang University, Hangzhou 310058, China. ${ }^{6}$ Institute of Insect Sciences, Zhejiang University, Hangzhou 310058, China.

Received: 2 July 2014 Accepted: 29 September 2014

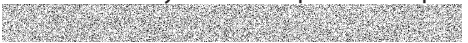

\section{References}

1. Pegg GF, Brady BL: Verticillium Wilts. Wallingford, UK: CABI Publishing; 2002

2. Fradin EF, Thomma BP: Physiology and molecular aspects of Verticillium wilt diseases caused by V. dahliae and V. albo-atrum. Mol Plant Pathol 2006, 7:71-86

3. Klosterman SJ, Atallah ZK, Vallad GE, Subbarao KV: Diversity, pathogenicity, and management of Verticillium species. Ann Rev Phytopathol 2009, 47:39-62.

4. Clerivet A, Deon V, Alami I, Lopez F, Geiger JP: Tyloses and gels associated with cellulose accumulation in vessels are responses of plane tree seedlings (Platanus $\times$ acerifolia) to the vascular fungus Ceratocystis fimbriata f. sp platani. Trees 2000, 15:25-31.

5. Cai Y, He X, Mo J, Sun Q, Yang J, Liu J: Molecular research and genetic engineering of resistance to Verticillium wilt in cotton: a review. Afr J Biotechnol 2009, 8:7363-7372.

6. Kawchuk LM, Hachey J, Lynch DR, Kulcsar F, van Rooijen G, Waterer DR, Robertson A, Kokko E, Byers R, Howard RJ, Fischer R, Prufer D: Tomato Ve disease resistance genes encode cell surface-like receptors. Proc Natl Acad Sci U S A 2001, 98:6511-6515.

7. Fradin EF, Zhang Z, Ayala JC, Castroverde CD, Nazar RN, Robb J, Liu CM Thomma BP: Genetic dissection of Verticillium wilt resistance mediated by tomato Ve1. Plant Physiol 2009, 150:320-332.

8. Fradin EF, Abd-El-Haliem A, Masini L, van den Berg GC, Joosten MH: Interfamily transfer of tomato Ve1 mediates Verticillium resistance in Arabidopsis. Plant Physiol 2011, 156:2255-2265.

9. Schaible L, Cannon OS, Waddoups V: Inheritance of resistance to Verticillium wilt in a tomato cross. Phytopathology 1951, 41:986-990.
10. Veronese P, Narasimhan ML, Stevenson RA, Zhu JK, Weller SC: Identification of a locus controlling Verticillium disease symptom response in Arabidopsis thaliana. Plant J 2003, 35:574-587.

11. Pantelides IS, Tjamos SE, Paplomatas EJ: Ethylene perception via ETR1 is required in Arabidopsis infection by Verticillium dahliae. Mol Plant Pathol 2010, 11:191-202.

12. Tjamos SE, Flemetakis E, Paplomatas EJ, Katinakis P: Induction of resistance to Verticillium dahliae in Arabidopsis thaliana by the biocontrol agent K-165 and pathogenesis-related proteins gene expression. Mol Plant-Microbe Interact 2005, 18:555-561.

13. Ellendorff $U$, Fradin EF, de Jonge R, Thomma BP: RNA silencing is required for Arabidopsis defense against Verticillium wilt disease. J Exp Bot 2009, 60:591-602.

14. Johansson A, Staal J, Dixelius C: Early responses in the ArabidopsisVerticillium longisporum pathosystem are dependent on NDR1, JA- and ET-associated signals via cytosolic NPR1 and RFO1. Mol Plant-Microbe Interact 2006, 19:958-969.

15. Ralhan A, Schöttle S, Thurow C, Iven T, Feussner I, Polle A, Gatz C: The vascular pathogen Verticillium longisporum requires a jasmonic acid-independent COI1 function in roots to elicit disease symptoms in Arabidopsis shoots. Plant Physiol 2012, 159:1192-11203.

16. Liu SY, Chen JY, Wang JL, Li L, Xiao HL, Adam SM, Dai XF: Molecular characterization and functional analysis of a specific secreted protein from highly virulent defoliating Verticillium dahliae. Gene 2013, 529:307-316.

17. Reusche M, Klásková J, Thole K, Truskina J, Novák O, Janz D, Strnad M, Spíchal L, Lipka V, Teichmann T: Stabilization of cytokinin levels enhances Arabidopsis resistance against Verticillium longisporum. Mol Plant-Microbe Interact 2013, 26:850-860.

18. Hu M, Pei BL, Zhang LF, Li Y: Histone H2B monoubiquitination is involved in regulating the dynamics of microtubules during the defense response to Verticillium dahliae toxins in Arabidopsis. Plant Physiol 2014, 164:1857-1865.

19. Gaspar YM, McKenna JA, McGinness BS, Hinch J, Poon S, Connelly AA, Anderson MA, Heath RL: Field resistance to Fusarium oxysporum and Verticillium dahliae in transgenic cotton expressing the plant defensin NaD1. J Exp Bot 2014, 65:1541-1550.

20. Roos J, Bejai S, Oide S, Dixelius C: RabGAP22 is required for defense to the vascular pathogen Verticillium longisporum and contributes to stomata immunity. PLoS One 2014, 9:e88187.

21. Tran VT, Braus-Stromeyer SA, Kusch H, Reusche M, Kaever A, Kühn A, Valerius O, Landesfeind M, Aßhauer K, Tech M, Hoff K, Pena-Centeno T, Stanke M Lipka $V$, Braus GH: Verticillium transcription activator of adhesion Vta2 suppresses microsclerotia formation and is required for systemic infection of plant roots. New Phytol 2014, 202:565-581.

22. Bu B, Qiu D, Zeng H, Guo L, Yuan J, Yang X: A fungal protein elicitor PevD1 induces Verticillium wilt resistance in cotton. Plant Cell Rep 2014, 33:461-470.

23. Agrios G: Plant Pathol. Burlington: Elsevier Academic Press; 2005

24. Klosterman SJ, Subbarao KV, Kang S, Veronese P, Gold SE, Thomma BP, Chen Z, Henrissat B, Lee YH, Park J, Garcia-Pedrajas MD, Barbara DJ, Anchieta A, de Jonge R, Santhanam P, Maruthachalam K, Atallah Z, Amyotte SG, Paz Z, Inderbitzin P, Hayes RJ, Heiman DI, Young S, Zeng Q, Engels R, Galagan J, Cuomo CA, Dobinson KF, Ma L: Comparative genomics yields insights into niche adaptation of plant vascular wilt pathogens. PLoS Pathog 2011, 7:e1002137

25. Mol L, Van Riessen HW: Effect of plant roots on the germination of microsclerotia of Verticillium dahliae 1. Use of root observation boxes to assess differences among crops. Eur J Plant Pathol 1995, 101:673-678.

26. Reusche M, Thole K, Janz D, Truskina J, Rindfleisch S, Drübert C, Polle A, Lipka $V$, Teichmann T: Verticillium infection triggers VASCULAR-RELATED NAC DOMAIN7-dependent de novo xylem formation and enhances drought tolerance in Arabidopsis. Plant Cell 2012, 24:3823-3837.

27. Zhao P, Zhao Y-L, Jin Y, Zhang T, Guo H-S: Colonization process of Arabidopsis thaliana roots by a green fluorescent protein-tagged isolate of Verticillium dahliae. Protein Cell 2014, 5:94-98.

28. Berg G, Fritze A, Roskot N, Smalla K: Evaluation of potential biocontrol rhizobacteria from different host plants of Verticillium dahliae Kleb. J Appl Microbiol 2001, 91:963-971. 
29. Li CH, Shi L, Han Q, Hu HL, Zhao MW, Tang CM, Li SP: Biocontrol of Verticillium wilt and colonization of cotton plants by an endophytic bacterial isolate. J Appl Microbiol 2012, 113:641-651.

30. Tjamos EC, Rowe RC, Heale JB, Fravel DR: Advances in Verticillium Research and Disease Management. St. Paul, MN: APS Press; 2000.

31. Oelmüller R, Sherameti I, Tripathi S, Varma A: Piriformospora indica, a cultivable root endophyte with multiple biotechnological applications. Symbiosis 2009, 49:1-17.

32. Qiang $X$, Weiss $M$, Kogel KH, Schäfer P: Piriformospora indica - a mutualistic basidiomycete with an exceptionally large plant host range. Mol Plant Pathol 2012, 13:508-518.

33. Selosse MA, Dubois MP, Alvarez N: Do Sebacinales commonly associate with plant roots as endophytes? Mycol Res 2009, 113:1062-1069.

34. Shahollari B, Vadassery J, Varma A, Oelmüller R: A leucine-rich repeat protein is required for growth promotion and enhanced seed production mediated by the endophytic fungus Piriformospora indica in Arabidopsis thaliana. Plant J 2007, 50:1-13.

35. Sherameti I, Shahollari B, Venus Y, Altschmied L, Varma A, Oelmüller R: The endophytic fungus Piriformospora indica stimulates the expression of nitrate reductase and the starch-degrading enzyme glucan-water dikinase in tobacco and Arabidopsis roots through a homeodomain transcription factor that binds to a conserved motif in their promoters. J Biol Chem 2005, 280:26241-26247.

36. Waller F, Achatz B, Baltruschat H, Fodor J, Becker K, Fischer M, Heier T, Hückelhoven R, Neumann C, von Wettstein D, Franken P, Kogel KH: The endophytic fungus Piriformospora indica reprograms barley to salt-stress tolerance, disease resistance, and higher yield. Proc Natl Acad Sci U S A 2005, 102:13386-13391.

37. Yadav V, Kumar M, Deep DK, Kumar H, Sharma R, Tripathi T, Tuteja N, Saxena AK, Johri AK: A phosphate transporter from the root endophytic fungus Piriformospora indica plays a role in phosphate transport to the host plant. J Biol Chem 2010, 285:26532-26544.

38. Baltruschat H, Fodor J, Harrach BD, Niemczyk E, Barna B, Gullner G, Janeczko A, Kogel KH, Schäfer P, Schwarczinger I, Zuccaro A, Skoczowski A: Salt tolerance of barley induced by the root endophyte Piriformospora indica is associated with a strong increase in antioxidants. New Phytol 2008, 180:501-510

39. Sun C, Johnson JM, Cai D, Sherameti I, Oelmüller R, Lou B: Piriformospora indica confers drought tolerance in Chinese cabbage leaves by stimulating antioxidant enzymes, the expression of drought-related genes and the plastid-localized CAS protein. J Plant Physiol 2010, 167:1009-1017.

40. Stein E, Molitor A, Kogel KH, Waller F: Systemic resistance in Arabidopsis conferred by the mycorrhizal fungus Piriformospora indica requires jasmonic acid signaling and the cytoplasmic function of NPR1. Plant Cell Physiol 2008, 49:1747-1751.

41. Grimmer MK, John Foulkes M, Paveley ND: Foliar pathogenesis and plant water relations: a review. J Exp Bot 2012, 63:4321-4431.

42. Hammes UZ, Schachtman DP, Berg RH, Nielsen E, Koch W, McIntyre LM, Taylor CG: Nematode-induced changes of transporter gene expression in Arabidopsis roots. Mol Plant-Microbe Interact 2005, 12:1247-1257.

43. Guan Y, Nothnagel EA: Binding of arabinogalactan proteins by Yariv phenylglycoside triggers wound-like responses in Arabidopsis cell cultures. Plant Physiol 2004, 135:1346-1366.

44. Manzoor H, Kelloniemi J, Chiltz A, Wendehenne D, Pugin A, Poinssot B, Garcia-Brugger A: Involvement of the glutamate receptor AtGLR3.3 in plant defense signaling and resistance to Hyaloperonospora arabidopsidis. Plant J 2013, 76:466-480

45. Johnson JM, Reichelt M, Vadassery J, Gershenzon J, Oelmüller R: An Arabidopsis mutant impaired in intracellular calcium elevation is sensitive to biotic and abiotic stress. BMC Plant Biol 2014, 14:162.

46. Zhao K, Penttinen P, Chen Q, Guan T, Lindström K, Ao X, Zhang L, Zhang X: The rhizospheres of traditional medicinal plants in Panxi, China, host a diverse selection of actinobacteria with antimicrobial properties. Appl Microbiol Biotechnol 2012, 94:1321-1335.

47. Maldonado-González MM, Bakker PA, Mercado-Blanco J: Use of Arabidopsis thaliana to study mechanisms of control of Verticillium wilt by Pseudomonas fluorescens PICF7. Commun Agric Appl Biol Sci 2012, 77:23-28.

48. Berg G, Krechel A, Ditz M, Sikora RA, Ulrich A, Hallmann J: Endophytic and ectophytic potato-associated bacterial communities differ in structure and antagonistic function against plant pathogenic fungi. FEMS Microbio/ Ecol 2005, 51:215-229.

49. El Hadrami A, Adam LR, Daayf F: Biocontrol treatments confer protection against Verticillium dahliae infection of potato by inducing antimicrobial metabolites. Mol Plant-Microbe Interact 2011, 24:328-335.

50. Prieto $P$, Schilirò E, Maldonado-González MM, Valderrama R, Barroso-Albarracín JB, Mercado-Blanco J: Root hairs play a key role in the endophytic colonization of olive roots by Pseudomonas spp. with biocontrol activity. Microb Ecol 2011, 62:435-445.

51. Guo Q, Li S, Lu X, Li B, Ma P: PhoR/PhoP two component regulatory system affects biocontrol capability of Bacillus subtilis NCD-2. Genet Mol Biol 2010, 33:333-340.

52. Müller H, Westendorf C, Leitner E, Chernin L, Riedel K, Schmidt S, Eberl L, Berg G: Quorum-sensing effects in the antagonistic rhizosphere bacterium Serratia plymuthica HRO-C48. FEMS Microbiol Ecol 2009, 67:468-478.

53. Garmendia I, Goicoechea N, Aguirreolea J: Moderate drought influences the effect of arbuscular mycorrhizal fungi as biocontrol agents against Verticillium-induced wilt in pepper. Mycorrhiza 2005, 15:345-356.

54. Li F, Wang J, Ma C, Zhao Y, Wang Y, Hasi A, Qi Z: Glutamate receptor-like channel3.3 is involved in mediating glutathione-triggered cytosolic calcium transients, transcriptional changes, and innate immunity responses in Arabidopsis. Plant Physiol 2013, 162:1497-1509.

55. Cao L, Wang L, Zheng $M$, Cao $H$, Ding L, Zhang $X$, Fu Y: Arabidopsis AUGMIN subunit8 is a microtubule plus-end binding protein that promotes microtubule reorientation in hypocotyls. Plant Cell 2013, 25:2187-2201

56. Cheong MS, Kirik A, Kim JG, Frame K, Kirik V, Mudgett MB: AvrBsT acetylates Arabidopsis ACIP1, a protein that associates with microtubules and is required for immunity. PLOS Pathog 2014, 10:e1003952.

57. Underwood W, Somerville SC: Perception of conserved pathogen elicitors at the plasma membrane leads to relocalization of the Arabidopsis PEN3 transporter. Proc Natl Acad Sci U S A 2014, 110:12492-12497.

58. Yuan HY, Yao LL, Jia ZQ, Li Y, Li YZ: Verticillium dahliae toxin induced alterations of cytoskeletons and nucleoli in Arabidopsis thaliana suspension cells. Protoplasma 2006, 229:75-82.

59. Yao LL, Pei BL, Zhou Q, Li YZ: NO serves as a signaling intermediate downstream of $\mathrm{H}_{2} \mathrm{O}_{2}$ to modulate dynamic microtubule cytoskeleton during responses to VD-toxins in Arabidopsis. Plant Signal Behav 2012, 7:174-177.

60. Wang B, Yang X, Zeng H, Liu H, Zhou T, Tan B, Yuan J, Guo L, Qiu D: The purification and characterization of a novel hypersensitive-like responseinducing elicitor from Verticillium dahliae that induces resistance responses in tobacco. Appl Microbiol Biotechnol 2012, 93:191-201.

61. Murashige T, Skoog F: A revised medium for rapid growth and bioassays with tobacco tissue cultures. Physiol Plant 1962, 15:473-497.

62. Hill TW, Kaefer E: Improved protocols for Aspergillus minimal medium: trace element and minimal medium salt stock solutions. Fungal Genet News/ 2001, 48:20-21.

63. Johnson JM, Sherameti I, Ludwig A, Nongbri PL, Sun C, Lou B, Varma A, Oelmüller R: Protocols for Arabidopsis thaliana and Piriformospora indica co-cultivation - A model system to study plant beneficial traits. Endocyt Cell Res 2011, 21:101-113.

64. Bains PS, Tewari JP: Purification, chemical characterization and hostspecificity of the toxin produced by Alternaria brassicae. Physiol Mol Plant Pathol 1987, 30:259-271.

65. Camehl I, Sherameti I, Venus Y, Bethke G, Varma A, Lee J, Oelmüller R: Ethylene signalling and ethylene-targeted transcription factors are required to balance beneficial and nonbeneficial traits in the symbiosis between the endophytic fungus Piriformospora indica and Arabidopsis thaliana. New Phytol 2010, 185:1602-1673.

66. Johnson JM, Lee Y-C, Camehl I, Sun C, Yeh K-W, Oelmüller R: Piriformospora indica promotes growth of Chinese cabbage by manipulating auxin homeostasis - role of auxin in Piriformospora indica symbioses. In Piriformospora indica: Sebacinales And Their Biotechnological Applications. Soil Biology Volume 33. 1st edition. Edited by Varma A, Kost G, Oelmüller R. Berlin Heidelberg Germany: Springer; 2013:325-343.

67. Naik ST, Lakkund LR: Diagrammatic representation of leaf area damage in tar spot of Dalbergia latifolia. Indian Forestry 1997, 124:1057-1058.

68. Wheeler BE: An Introduction to Plant Diseases. London: John Wiley and Sons Limited; 1969

69. Vadassery J, Reichelt M, Hause B, Gershenzon J, Boland W, Mithöfer A: CML42-mediated calcium signaling coordinates responses to 
Spodoptera herbivory and abiotic stresses in Arabidopsis. Plant Physiol 2012, 159:1159-1175.

70. Yang Y: Study on rapid determination of chlorophyll content of leaves. Chin I Spectroscopy Lab 2002, 19:478-481.

71. Vadassery J, Ranf S, Drzewiecki C, Mithöfer A, Mazars C, Scheel D, Lee J, Oelmüller R: A cell wall extract from the endophytic fungus Piriformospora indica promotes growth of Arabidopsis seedlings and induces intracellular calcium elevation in roots. Plant J 2009, 59:193-206.

72. Knight MR, Campbell AK, Smith SM, Trewavas AJ: Transgenic plant aequorin reports the effects of touch and cold-shock and elicitors on cytoplasmic calcium. Nature 1991, 352:524-526.

73. Zhen XH, Li YZ: Ultrastructural changes and location of beta-1, 3-glucanase in resistant and susceptible cotton callus cells in response to treatment with toxin of Verticillium dahliae and salicylic acid. J Plant Physiol 2004, 161:1367-1377.

doi:10.1186/s12870-014-0268-5

Cite this article as: Sun et al.: The beneficial fungus Piriformospora indica protects Arabidopsis from Verticillium dahliae infection by downregulation plant defense responses. BMC Plant Biology 2014 14:268.

\section{Submit your next manuscript to BioMed Central and take full advantage of:}

- Convenient online submission

- Thorough peer review

- No space constraints or color figure charges

- Immediate publication on acceptance

- Inclusion in PubMed, CAS, Scopus and Google Scholar

- Research which is freely available for redistribution 